\title{
PENINGKATAN KEMAMPUAN MENULIS POPULER MAHASISWA MELALUI PENDEKATAN WHOLE LANGUAGE DENGAN PEMBUATAN MEDIA STORY BOARD
}

\author{
${ }^{1)}$ Siti Ansoriyah, ${ }^{2)}$ Aceng Rahmat \\ ${ }^{1)}$ 2) Universitas Negeri Jakarta \\ E-mail: siti.ansoriyah@unj.ac.id
}

\begin{abstract}
ABSTRAK
Penelitian ini bertujuan untuk memperoleh data empirik tentang kegiatan menulis populer menggunakan pendekatan whole language dengan pembuatan media story board mahasiswa pendidikan bahasa Indonesia. Penelitian ini dilakukan di prodi pendidikan bahasa Indonesia, dalam mata kuliah menulis populer, dengan menggunakan metode classroom action research. Desain yang digunakan menggunakan model Kemmis dan Taggart, data dilakukan dengan melakukan observasi dan tes keterampilan menulis. Analisis penelitian dilakukan dengan (1) reduksi data, (2) display data, (3) kesimpulan, verivikasi, dan refleksi. Hasil penelitian menunjukan adanya peningkatan nilai kemampuan menulis populer mahasiswa pada setiap siklus. Sehingga dapat disimpulkan bahwa pembelajaran menulis dengan menerapkan metode whole language dapat menciptakan story board dalam menulis populer mahasiswa.
\end{abstract}

Kata kunci: pembelajaran menulis populer, pendekatan whole language, story board

\begin{abstract}
The objective of this research is to gain empiric data on activites of popular writing using the whole language approach through story board preparation by the college students of Indonesian language education. The research was conducted at educational program of Indonesian literature in popular writing subject. The research used classroom action research. The research adopted Kemmis and taggart model through observation and writing proficiency test. Research analysis was performed using (1) data reduction, (2) data display, (3) conclusion, verification and reflection. The result of the research shows improvement in students popular writing score in every cycle. It can be concluded that the use of whole language method could produce story board in students' popular writing.
\end{abstract}

Keywords: study populer writing, whole language method, story board 


\section{PENDAHULUAN}

Salah satu kemampuan berbahasa yang sangat penting dimiliki mahaiswa adalah kemampuan menulis. Menulis merupakan sebuah keterampilan berbahasa dan merupakan kemampuan seseorang di dalam mengemukakan sebuah gagasan, perasaan, dan juga pemikiran-pemikiran yang dimiliki seseorang ataupun pihak lainnya dengan menggunakan sebuah media tulisan. (Darwis, 2011). Kegiatan menulis adalah sebuah proses yang bukan hanya berkaitan dengan tata bahasa, dan tanda baca saja melainkan dapat mengembangkan kemampuan berpikir dinamis serta dapat mengembangkan kosakata dengan baik. Keterampilan menulis merupakan hal yang penting dalam kehidupan sebagai modal dasar seseorang untuk berhasil (Kurniadi, 2017; Utami, 2017).

Seorang yang telah terampil menulis, mereka telah melalui proses latihan yang terus- menerus. Kemampuan menulis ini dapat berdampak positif pada diri seseorang. Lebih dari itu, kegiatan menulis dapat meningkatkan rasa percaya diri dan memunculkan kreativitas baru. Dalam mata kuliah menulis populer, mahasiswa dituntut untuk dapat mengembangkan tulisannya dengan baik. Tidak hanya memahami dari segi tulisan tetapi isi dari tulisannya harus bagus. Akam tetapi, pada kenyataannya masih banyak mahasiswa yang kesulitan dalam mengembangkan ide, penggunaan kaidah bahasa yaitu ketika diadakan pengamatan di kelas, baru sebagian kecil yang dapat mengembangkan idenya, sebagian besar masih bingung dalam pembentukan tema. Sehingga hasil penulisan populernya kurang maksimal.

Dari masalah tersebut, mahasiswa kemudian diminta untuk membuat media sebagai daya tarik pembelajaran tersebut, namun masih juga terjadi juga berbagai 
kendala, masih banyak mahasiswa yang belum dapat membuat dan memahamai aplikasi dari program tersebut. Kegiatan tersebut jika tidak diatasi, sesuai dengan kreativitas mahasiswa masing-masing, jika hal tersebut dibatasi, maka hal tersebut akan menyebabkan kegiatan menulis menjadi terhambat. Pembelajaran yang dilaksanakan umumnya belum mengoptimalkan mahasiswa aktif dalam menulis dan kegiatan menulis. Dalam hal inilah maka bagaimana kegiatan menulis dan kegiatan pengembangan multimedia menjadi budaya bagi mahasiswa. Pembelajaran menulis populer tidak hanya memprioritaskan pada penguasaan kaidah menulis secara teoritis tetapi dapat juga mengembangkan menjadi banyak multimedia yang menarik, karena sekarang ini telah memasuki tahap revolusi industri 4.0 yang akan menuju ketahap 5.0, manusia tidak bergantung lagi dengan manusia lainnya tetapi kegiatan manusia akan dibantu dengan teknologi modern.

Pembelajaran menulis umumnya lebih ditekankan pada teori, menyebabkan mahasiswa bosan dan tidak tertarik untuk menulis, kegiatan menulis pun sebelumnya kurang ditekankan dan jarang menghargai prosesnya. Kegiatan menulis mahasiswa untuk mengekspresikan atau mengungkapkan gagasan secara kreatif melalui tulisan. Kegiatan menulis lebih ditekankan pada rapi atau tidaknya tulisan mahaiswa, topiktopik yang ditulis pada apa yang telah dialami dan dinikmati mahasiswa. Berdasarkan latar belakang diatas, maka rumusan masalahnya adalah bagaimana meningkatan mahasiswa dalam menulis populer dengan pendekata whole language untuk menciptakan story board yang efektif, praktis dan bermutu? 
Pada hakikatnya menulis adalah (Tarigan, 1995) mengekpresikan secara tertulis gagasan, ide, pendapat, atau pikiran dan perasaan. Sarana mewujudkan hal itu adalah bahasa. Isi ekspresi melalui bahasa itu akan dimegerti orang lain atau pembaca bila dituangkan dalam bahasa yang teratur, sistematis, sederhana, dan mudah dimengerti. Hal ini dimaksudkan untuk dapat menyampaikan, menceritakan, memberitakan, melukiskan, menerangkan, menjelmakan dan sebagainya kepada pembaca agar memahami apa yang terjadi pada peristiwa atau kegiatan. Cere (1985: 4) mengungkapkan bahwa menulis merupakan sebuah komunikasi, di dalam komunikasi terdapat empat unsur bahwa menulis merupakan (1) bentuk ekspresi diri, (2) sesuatu yang umum yang disampaikan pembaca, (3) aturan dan tingkah laku, serta (4) menulis merupakan sebuah cara belajar. Sebagai bentuk dari ekspresi diri, menulis bertujuan untuk mengomunikasikan, menyampaikan sebuah ide melewati batas waktu dan ruang. Artinya, menulis dapat dilakukan kapan saja, di mana saja dan dalam keadaan seperti apa penulis dapat mengekspresikan idenya dalam tulisan

Menulis merupakan suatu proeses penemuan yang kompleks dan membuat sesorang dapat belajar mengatur waktunya Menulis merupakan suatu refleksi diri yang tumbuh melalui suatu proses. Seseorang yang dapat menulis dengan baik, tentunya telah melalui berbagai latihan yang terus menerus, dengan latihan yang teratur dan konsisten ditambah dengan adanya kegemaran seseorang, menulis akan berimplikasi kepada kegiatan hasil menulsnya dan dapat dilihat hasil akhirnya. Akhadiah (1992: 2) mengemukakan bahwa menulis merupakan kemampuan yang kompleks yang menuntut sebuah pengetahuan dan keterampilan. Dapat dismpulkan bahawa dalam mencapai taraf mampu menulis diperlukan berbagai syarat pendukung. Kegiatan menulis 
membutuhkan suatu kemampuan yang cermat dan terintegrasi dalam mengorganisasikan tulisan. Tulisan populer biasanya tulisan ringan yang tidak rumit dan bersifat hiburan. Tulisan baik bersifat fiksi maupun non fiksi asalkan pembaca dapat menangkap pesan sesuai dengan yang ingin disampaikan. Bahasa dan istilahnya sederhana, mudah dicerna dan pupler di masyarakat. Materinya tidak selalu harus berdasarkan pada fakta-fakta empirik (penelitian), boleh juga dari hasil pengamatan atau perenungan (refleksi). Hal ini menunjukkan bagaimana penulis dapat menyampaikan kepada pembaca sesuai dengan cara menulis dan pemikiran mereka sendiri.

Menurut Eneste (2005) Penulisan populer memiliki ciri, bentuk, bahasa, serta kiat dan praktik penulisan yang khas. Tujuan menulis tulisan populer sekadar memberikan sumbangan pemikiran berdasarkan informasi atau wawasan penulisnya dan selanjutnya (lazimnya diharapkan) sebagai bahan wacana atau diskursus tentang topik itu bagi pembacanya. Materinya tidak selalu harus berdasarkan pada fakta-fakta empirik (penelitian), boleh juga dari hasil pengamatan atau perenungan (refleksi). Pembahasan dan analisis tidak perlu terlalu mendalam dan rinci, namun logika serta sistematika pemikiran harus tetap diperhatikan, agar pembaca dapat menangkap pesan sesuai dengan yang ingin disampaikan.

Pembahasan dan analisisnya sedapat mungkin menggunakan kata-kata, istilahistilah atau kalimat yang mudah dicerna dan sudah populer di masyarakat. Semua itu tidak harus secara ketat mengikuti "aturan main" penggunaan tata bahasa yang berlaku di dunia akademik (Wiyata, 2008). Dapat disimpulkan bahwa tulisan populer adalah tulisan yang bersifat ringan dan menghibur, materi yang diungkapkan tidak harus melalui fakta yang empirik tetapi dapat juga berdasarkan pengamatan tetapi dapat juga 
dari hasil refleksi. Pembahasan dan analisis tidak perlu terlalu mendalam dan rinci, namun logika serta sistematika pemikiran harus tetap diperhatikan, agar pembaca dapat menangkap pesan sesuai dengan yang ingin disampaikan

Finoza (2002) merumuskan sepuluh alasan mengapa gemar menulis itu penting (1) rasa suka terhadap suatu kegiatan merupakan prasyarat untuk keberhasilan di bidang apapun, demikian pula halnya dalam menulis, (2) peserta didik yang menulis dengan sering dan teliti, merupakan seorang penulis yang ulung, (3) peserta didik yang gemar menulis dan banyak menulis secara mandiri yang dapat mengembangkan irama dan gaya pribadi, (4) peserta didik yang terbiasa menulis mandiri sajalah yang akan belajar dengan cara menulis dengan fokus yang tajam dan jelas, (5) peserta didik harus sering dan bebas menulis (serta membaca) supaya prigel (sangat terampil), dalm menggunakan struktur kalimat yang kompleks dan benar serta tata bahasa, (6) peserta didik yang menikmati tulis-menulis jarang menunda-nunda menyerahkan makalah atau laporan yang ditugaskan, (7) peserta didik yang suka menulis dan sering menulis untuk sakadar iseng saja yang lebih memahami hal-hal yang dibacanya, (8) peserta didik yang gemar menulis (membaca) menjadi siswa yang mudah unggul dalam hampir semua mata pelajaran, (9) peserta didik dengan kebiasaan menulis pribadi yang mandiri mempunyai cara yang mudah untuk mengatasi trauma emosional, serta (10) penulis yang prigel dan fasih mempunyai keunggulan luar biasa dalam sebagian besar bidang pekerjaan.

Santoso (2004) mengungkapkan ada beberapa prinsip yang harus diperhatikan dalm pembelajaran menulis yang dikemukakan yang pertama, praktik terlebih dahulu, teori belakangan, artinya dalam kegiatan menulis tidak harus dimulai dengan pemahaman kaidah-kaidah menulis, sebaiknya dapat dilakukan ketika dalam proses 
menulis. Kedua, menulis sambil "bercanda" artinya menulis harus dilaksanakan dalam suasana yang menyenangkan dan tidak membuat siswa tertekan. Ketiga, kegiatan menulis memerlukan umpan balik, artinya agar peserta didik dapat mengetahui letak kesalahan dan kekurangannya.

Whole language adalah suatu pendekatan yang menyajikan pembelajaran bahasa secara menyeluruh dan utuh. Weaver dalam Santoso (2004) menyatakan bahwa pada dasarnya whole language merupakan suatu fungsi yang mengajarkan peserta didik secara alami. Pembelajaran bahasa dengan pendekatan whole language menenggelamkan peserta didik ke dalam suatu lingkungan yang penuh dengan suatu rangsangan berbahasa. Dengan whole language peserta didik belajar bahasa dengan penggunaan literatur yang sebenarnya dan pengalaman menulis yang bernakna. Pendekatan whole language didasari oleh paham kontruktivisme yang menyatakan bahwa peserta didik membentuk sendiri pengetahuannya melalui peran aktifnya belajar secara utuh dan terpadu. Peserta didik akan termotivasi untuk belajar jika melihat bahwa yang dipelajarinya itu diperlukan. Oleh sebab itu, pendidik berkewajiban untuk menyediakan lingkungan yang menunjang agar peserta didik dapat belajar dengan baik.

Belajar menulis dalam kelas yang dilakukan mahasiswa merupakan whole language dari keseluruhan ke bagian-bagian yang lebih ditekankan. Belajar dimulai dari yang konkret ke yang abstark. Pengajaran didasarkan pada transaksional atau teori transformasi dalam membaca. Pengajaran dikaitkan dengan teori gestalt yaitu belajar bahasa didasarkan pada pengalaman dan relevansi personal yang merupakan kekuatan dari dalam yang memotivasi siswa. Dilain pihak, penghargaan dari luar tidak diberikan sebagai ganjaran terhadap perilaku peserta didik. Ciri-ciri kelas yang menerapkan whole 
language adalah adanya pusat konferensi, yaitu tempat peserta didik mendiskusikan hasil pelaksanaan tugas, tersedianya perpustakaan kelas, pusat publikasi hasil karya peserta didik dan tempat peserta didik membaca dan menulis dengan rasa aman dan nyaman. (Santosa, 2004). Dalam hal ini, dimaksudkan bahwa suasana belajar di sekolah disesuaikan dengan situasi belajar di rumah yaitu dibuat dengan suasana nyaman. Pengelompokan mahasiswa di kondisikan sesuai dengan keinginan mahasiswa itu sendiri, sesuai dengan minat dan kemauan mahasiswa. Mahasiswa harus dipicu untuk berpikir di luar kebiasaan yang ada, melibatkan cara berpikir yang baru, memperoleh kesempatan untuk menyampaikan ide-ide dan solusi-solusi baru, mengajukan pertanyaan yang tidak lazim, dan mencoba mengajukan dugaan jawaban. Kesuksesan individu akan didapatkan oleh mahasiswa yang memiliki keterampilan kreatif.

Seseorang terampil menulis membutuhkan latihan yang berulang-ulang, karena keterampilan itu memerlukan proses melalui banyaknya latihan. Pembelajaran menulis populer diberikan kepada mahasiswa dengan memperkenalkan lingkungan melalui berbagai gendre teks yang dihasilkan. Pada pembelajaran whole language, dosen menekankan cara berpikir bagaimana mahasiswa dapat belajar bahasa melalui tulisan populer dengan menggunakan berbagai jenis teks yang diciptakan melalui media story board. Mahasiswa adalah individu yang kreatif, mampu menyusun, menciptakan dan menemukan pemecahan terhadap persoalan secara aktif jika diberi kesempatan untuk melakukan kegiatan yang sesuai dengan kemampuannya. Dalam kegiatan menulis populer dengan membuat story board, mahasiswa diberi kewenangan untuk bertanggungjawab terhadap apa yang mereka buat dan kembangkan untuk memenuhi tujuan pembelajaran. Berdasarkan uraian di atas, maka hipotesis yang diajukan dalam 
penelitian ini adalah dengan menerapkan story board dengan pendekatan whole languange maka kemampuan menulis populer mahasiswa prodi pendidikan bahasa Indonesia akan meningkat.

\section{METODE}

Penelitian ini bertujuan untuk memperoleh data empirik mengenai kegiatan menulis populer menggunakan pendekatan whole language dengan mengembangkan story board mahasiswa prodi pendidikan bahasa Indonesia. tempat dilaksanakannya penelitian di gedung Dewi Sartika lantai 407 Univeritas Negeri Jakarta. Penelitian ini adalah penelitian action research yang bertujuan untuk memperbaiki efektivitas dan efisiensi dalam pembelajaran menulis populer.

Penelitian ini berdasarkan prosedur kerja yang menggunakan model Kemmis dan Tagart yang meliputi (1) tahap perencanaan, (2) tindakan, (3) observasi, (4) refleksi. Setelah mahasiswa dapat membuat story board lewat hasil menulis populer melalui pendekatan whole language. Adapun teknik yang digunakan dalam menjaring data melalui observasi (pengamatan), pengamatan dilakukan ketika melakukan kegiatan di kelas, sedangkan teknik pengumpulan data yang digunakan untuk menjaring data penelitian adalah tes keterampilan menulis populer dan pembuatan story boardnya. Analisis data penelitian dilakukan dengan menggunakan analisis sebagaimana yang dikemukakan Miles dan Huberman, yakni melalui tahapan (1) reduksi data, (2) display data, (3) kesimpulan. 


\section{HASIL DAN PEMBAHASAN}

\section{Siklus I}

Pada siklus I dilaksanakan sebanyak empat kali pertemuan. Pertemuan pertama 7 maret 2018. Pada siklus ini peneliti telah melakukan rancangan pembelajaran dengan menerapkan whole language melalui kegiatan menulis populer. Adapun proses yang dilakukan dosen adalah pada kegiatan pertama mahasiswa diminta untuk memahami tentang teks gendre, dengan berbagai topik yang telah ditentukan dosen. Setelah mahasiswa membentuk kelompok berdasarkan masing-masing teks gendre yang telah ditentukan, mahasiswa mulai menulis, dari hasil tulisannya tersebut, kemudian mahasiswa membuat naskah dari hasil tulisan populer, dan membuat power point yang sederhana untuk dilanjutkan menjadi story board.

Setiap kelompok masing-masing mempunyai peran sehingga dapat terwujud pembuatan story boardnya. Mereka berdiskusi saling memberi komentar terhadap hasil pekerjaan temannya. Komentar dari temannya sangat membantu untuk lebih menyempurnakan pembuatan story board tersebut. Dosen mengamati proses pembelajaran tersebut dengan mencatat selama kegiatan pembelajaran, sesekali memberikan komentar dan masukan hasil pembuatan karya mahasiswa. Pelaksanaan pengamatan ini diperlukan untuk mengevaluasi sejauh mana peningkatan hasil penulisan populer yang diaplikasikan lewat multimedia tersebut. Adapun hasil perolehan nilai menulis populer yang dilakukan pada siklus I 
Tabel 1. Nilai Mahasiswa Menulis Populer dengan Membuat Story Board

\begin{tabular}{|l|l|l|l|}
\hline Kelompok & \multicolumn{1}{|c|}{ Nilai } & Banyaknya mahasiswa & Persentase \\
\hline 1 & $<75$ & 5 & $30 \%$ \\
\hline 2 & $<80$ & 5 & $40 \%$ \\
\hline 3 & $<70$ & 5 & $27 \%$ \\
\hline 4 & $<75$ & 6 & $30 \%$ \\
\hline 5 & $<80$ & 6 & $40 \%$ \\
\hline
\end{tabular}

Berdasarkan tabel di atas, terlihat bahwa nilai mahasiswa dalam menulis populer masih rendah. Berdasarkan perolehan nilai pada siklus I, dapat ditarik kesimpulan bahwa (1) kemampuan mahasiswa dalam menulis populer masih rendah, (2) pembuatan story boardnya masih sangat sederhana. Maka penelitian ini dilanjutkan ke siklus berikutnya sampai memenuhi target yang diharapkan yaitu sesuai dengan pedoman penilaian dari Universitas Negeri Jakarta.

\section{Siklus II}

Perencanaan tindakan pada siklus II dalam penelitian ini disusun berdasarkan masalah yang hendak dipecahkan, yaitu melalui peningkatan kemampuan menulis populer pada mahasiswa program studi pendidikan bahasa Indonesia. Pada tahap ini, peneliti merancang tentang waktu penelitian, rencana pembelajaran, metode mengajar. Rencana tindakan pada siklus II adalah pembelajarn menulis populer menggunakan whole language dengan tema penulisan iklan, penulisan opini, penulisan ulasan, penulisan feature. 
Siklus II ini dilaksanakan sebanyak empat pertemuan pada rabu 11 April- 2 Mei 2018. Pembelajaran tindakan kelas ini dilakukan dengan menerapkan whole language dalam pembelajaran menulis populer melalui beberapa tahapan yaitu mahasiswa menulis pokok-pokok gendre teks yang mereka buat, kemudian mengamati dan mempelajari contoh media story board yang telah diberikan, mempelajari langkahlangkah membuat story board, membuat power point sederhana untuk pembuatan story board. Kegiatan pembelajaran pada siklus II baru menghasilkan tulisan dan pembuatan story board dengan sederhana. Tahap yang dilakukan mahasiswa secara berkelompok adalah membuat ppt berdasarkan buku menulis populer, setelah membuat ppt, mahasiswa membuat naskah dengan memperhatikan durasi, suara, memperhatikan pula warna, gambar serta kecepatannya. Mahasiswa dalam membuat story board diajak ke luar kelas untuk mengamati lingkungan kampus. Diharapkan dalam hal ini untuk tidak membuat jenuh dan dapat menginspirasi dalam menulis naskah untuk dijadikan story board. Mahasiswa berbagi tanggungjawab dalam pembelajaran melalui belajar kooperatif. Mahasiswa terlibat secara aktif dalam pembelajaran bermakna, berani untuk mengambil resiko dan bebas bereksperimen, serta mahasiswa mendapat balikan positif dari dosen maupun temannya atas hasil yang mereka lakukan.

Kegiatan pembelajaran pada siklus ke II baru menghasilkan penulisan naskah yang sederhana berdasarkan pengkajian dan pengamatan lingkungan sekitar, sehingga diharapkan dapat menjadi sebuah naskah yang utuh. Pada tahap pengamatan, tim peneliti mengamati proses pembelajaran menulis populer menggunakan pendekatan whole language. Berdasarkan catatan observasi pada waktu kegiatan pembelajaran dan memeriksa hasil tulisan mahasiswa, dosen melakukan diskusi dan evaluasi. Diskusi dan 
evaluasi mengenai pelaksanaan pembelajaran dan hasil menulis populer mahasiswa pada sikluas II bertujuan untuk mengetahui sejauh mana peningkatan mahasiswa menghasilkan naskah yang telah ditulisnya. Adapun pemerolehan nilai menulis pada siklus II yaitu

Tabel 2. Nilai Mahasiswa dalam Menulis Populer dengan Membuat Story Board Tahap II

\begin{tabular}{|l|l|l|l|}
\hline Kelomp & Nilai & Kelompok & Persentase \\
\hline 1 & $<80$ & 5 & $40 \%$ \\
\hline 2 & $<85$ & 5 & $70 \%$ \\
\hline 3 & $<80$ & 5 & $40 \%$ \\
\hline 4 & $<80$ & 6 & $40 \%$ \\
\hline 5 & $<85$ & 6 & $70 \%$ \\
\hline
\end{tabular}

Berdasarkan tabel terlihat bahwa nilai mahasiswa dalam menulis populer dengan pembuatan story board masih dibawah target yang diharapkan, mahasiswa masih memperoleh nilai kurang dari A. Berdasarkan perolehan pada siklus II, maka dapat ditarik kesimpulan bahwa (1) kemampuan mahasiswa dalam membuat story board berdasarkan tulisan populer masih dibawah target yang diharapkan, (2) substansi isi yang dituliskan masih kurang dan belum mendalam, (3) pengisian suara dalam story board belum sesuai yang diharapkan karena volume yang dihasilakan masih sangat kecil, (3) tulisan dan warna belum sesuai, (4) kecepatan penampilan setiap selandia masih kurang. Dengan demikian, maka penelitian ini masih perlu dilanjutkan sampai memenuhi target yang diharapkan.

\section{Siklus III}

Perencanaan tindakan pada siklus III dalam penelitian ini disusun berdasarkan masalalah yang hendak dipecahkan yaitu upaya meningkatkan keterampilan menulis 
populer dengan mengguanakan metode whole language untuk pembuatan story board mahasiswa pendidikan bahasa Indonesia. Pada tahap ini peneliti merancang tentang rencana pembelajaran, skenario tindakan, strategi pembelajaran, metode pembelajaran dan media pembelajaran. Disamping itu juga mengenai pembuatan istrumen untuk penilaian menulis populer mahasiswa dalam pembuatan story board dengan menggunakan metode whole language.

Siklus III dilakukan sebanyak empat kali pertemuan yaitu pada 9-30 mei 2018. Pada tahap ini peneliti melakukan tindakan pembelajaran sesuai dengan langkahlangkah yang tertera dalam skenario rencana tindakan. Pada siklus III dilakukan sebanyak empat kali pertemuan. Tindakan yang dilakukan adalah menetapkan pendekatan whole language dalam pembelajaran menulis populer dengan tahap mengamati bahasa yang digunakan, mencatat semua hal yang menarik dan sesuai dengan isi dalam menulis populer. Mahasiswa berbagi tanggungjawab dalam pembelajaran melalui belajar kooperatif dalam pembelajaran bermakna, mahasiswa harus berani mengambil resiko dan bebas bereksperimen. Mahasiswapun bebas bereksperimen untuk mendapatkan hasil yang maksimal dari pembuatan story board berdasarkan menulis populer. Serta mendapatkan umpan balik baik dari temannya maupun dari dosen pengampu.

Kegiatan pembelajaran pada siklus III sudah mengalami peningkatan yang cukup signifikan. Dosen mengamati proses pembelajaran menulis populer dan membuat story boardnya dengan pendekatan whole language. Peningkatan kemampuan menulis populer dengan whole language, yaitu mahasiswa melakukannya dengan pengamatan, mencari bahan dari sumber lain dari berbagai media, sehingga pembelajaran menulis 
populer dengan pembuatan story board berjalan dengan lancar dan telah terjadi peningkatan sesuai yang diharpkan.

Tabel 3. Nilai Mahasiswa dalam Menulis Populer dengan Membuat Story Board Tahap II

\begin{tabular}{|l|l|l|l|}
\hline Kelomp & Nilai & Kelompok & Persentase \\
\hline 1 & $<87$ & 5 & $80 \%$ \\
\hline 2 & $<89$ & 5 & $90 \%$ \\
\hline 3 & $<87$ & 5 & $80 \%$ \\
\hline 4 & $<87$ & 6 & $80 \%$ \\
\hline 5 & $<89$ & 6 & $90 \%$ \\
\hline
\end{tabular}

Pembelajaran menulis populer dengan pendekatan whole language yaitu pembuatan story board, melatih mahasiswa dalam menulis secara alamiah dan terpadu. Dalam pelaksanaan pembelajaran menulis populer yang ditekankan bukan hanya pengembangan penulisannya saja tetapi pembauatan multi media story board, hal ini akan berdampak pada mutu pembelajaran menulis populer, karena mahasiswa lebih tertarik dalam pembelajarannya, story board ini berbeda dengan power point biasa. Story board ini menggunakan suara (audio) dan permaian warna juga tulisan yang menarik. Pembelajaran menulis populer dengan pembuatan story board dilakukan secara alamiah dan berpusat kepada mahasiswa. Untuk menstimulasi kemampuan menulisnya, mahasiswa betul-betul tenggelam dalam kemampuan membaca dan menulisnya dengan baik. Kelas yang menerapkan whole language tidak langsung ditekankan pada bahasa yang baku karena menulis populer bahasa lebih populer dan sederhana. Dapat disimpulkan bahwa dengan menggunakan pendekatan whole language dalam pembelajaran menulis populer untuk pembuatan story board dapat meningkatkan kemampuan mahasiswa dalam menulis sekaligus juga dalam kemampuan membacanya. Tindakan dilakukan dalam tiga siklus untuk meningkatkan keterampilan menulis dalam 
pembuatan story boardnya. Pembuatan story board ini tidak dapat dilakukan dengan waktu yang cukup singkat karena memerlukan latihan secara terus menerus (kontinu) presentase kenaikan nilai menulis populer dengan pembuatan story board meningkat pada siklus III ini.

Dilihat dari rerata kemmapuan menulis populer dengan pembuatan story board pada siklus I mencapai 30\%, pada siklus II mencapai 60\% dan pada siklus III mencapai 90\% hasil tersebut menandakan bahwa kriteria ketuntasan maksimal yang ditetapkan berdasarkan kriteria penenilaian Universitas Negeri Jakarta telah tercapai. Ketercapaian peningkatan skor menulis populer tersebut karena dosen menggunakan pendekatan whole language. Pendekatan whole language menyebabkan mahasiswa belajar bahasa dimulai dari yang sederhana ke yang lebih kompleks, sehingga berdampak pada kekuatan dari dalam yang memotivasi mahasiswa untuk belajar. Dosen harus juga memperhatikan lingkungan kelas agar belajar bahasa mellaui pendekatan whole language dapat berhasil secara optimal, antara lain, suasana belajar yang nyaman, pembentukan kelompok yang luwes, terciptanya kolaborasi antara dosen dan mahasiswa. Mahasiswa juga dipersiapkan untuk merencanakan kegiatan belajar mereka sendiri. Mahasiswa saling membantu antrtemannya baik dalam aktivitas belajar maupun dalam proses pembuatan story boardnya.

\section{KESIMPULAN}

Berdasarkan pembahasan dapat diperoleh kesimpulan bahawa pembelajaran menulis dengan mempersiapkan pembuatan story board yang merupakan salah satu komponen pendekatan whole language dapat meningkatkan kemampuan menulis 
populer mahasiswa dan dalam pembuatan story board. Hal ini ditandai dengan adanya peningkatan nilai kemampuan menulis populer dengan pembuatan story board pada setiap siklus. Selain itu, dalam proses pembelajaran terlihat mahasiswa lebih aktif dan antusias. Kegiatan menulis juga merupakan kegiatan yang menyenangkan dan bukan merupakan kegiatan yang sulit bagi mahasiswa. Hal ini salah satunya dengan pendekatan whole language. Pembalajaran dilakukan secara kontekstual dan alami. Apa yang dilakukan sesuai apa yang diketahui mahasiswa dan dosen memberikan stimulus, kemudian mahasiswanya yang mengembangkan.

\section{UCAPAN TERIMA KASIH}

Terima kasih kami ucapkan kepada Direktorat Riset dan Pengabdian Masyarakat-Diektorat Jendral Penguatan Riset dan Pengembangan - Kementrian Riset, Teknologi, dan Pendidikan Tinggi Republik Indonesia yang telah mendanai penelitian ini. Penghargaan kami sampaikan juga kepada Program Studi Pendidikan Bahasa Indonesia dan LPPM UNJ.

\section{DAFTAR PUSTAKA}

Akhadiah. (1992). Pemahaman kemampuan menulis bahasa Indonesia. Jakarta: Grasindo.

Avelrod, R.B. C. C. (1998). Guide to writing. New York: Saint Martin' press

Cere, A. R.. (1995). Writing and learning. New York: Mc Millan Publishing Company. 
Kurniadi, F. (2017). Penulisan karya tulis ilmiah mahasiswa dengan media aplikasi pengolah kata. Aksis: Jurnal Pendidikan Bahasa dan Sastra Indonesia, 1(2). 267-277. doi: doi.org/10.21009/AKSIS.010208

Karsana, A. (2002). Keterampilan menulis. Jakarta: Karunika.

Finoza, L. (2002). Komposisi bahasa Indonesia. Jakarta: Diksi Insan Mulia

Tarigan. (1985). Menulis sebagai salah satu keterampilan berbahasa. Bandung: Rosda Karya.

Utami, S. R. (2017). Pembelajaran Aspek Tata Bahasa dalam Buku Pelajaran Bahasa Indonesia. Aksis: Jurnal Pendidikan Bahasa dan Sastra Indonesia, 1(2). 189203. doi: doi.org/10.21009/AKSIS.010203 